\title{
Caddo Origins, A Smith County Perspective
}

\section{Mark Walters}

Heritage Research Center, Stephen F. Austin State University

Follow this and additional works at: https://scholarworks.sfasu.edu/ita

Part of the American Material Culture Commons, Archaeological Anthropology Commons, Environmental Studies Commons, Other American Studies Commons, Other Arts and Humanities Commons, Other History of Art, Architecture, and Archaeology Commons, and the United States History Commons

Tell us how this article helped you.

This Article is brought to you for free and open access by the Center for Regional Heritage Research at SFA ScholarWorks. It has been accepted for inclusion in Index of Texas Archaeology: Open Access Gray Literature from the Lone Star State by an authorized editor of SFA ScholarWorks. For more information, please contact cdsscholarworks@sfasu.edu. 


\section{Caddo Origins, A Smith County Perspective}

Creative Commons License

(c) (i) @ (9)

This work is licensed under a Creative Commons Attribution-NonCommercial 4.0 International License 


\title{
Caddo Origins, A Smith County Perspective
}

\author{
Mark Walters
}

\section{INTRODUCTION}

Attempting to trace Caddo Origins in Smith County and surrounding counties depends a lot on what we end up defining as Caddo. Separating the Caddo culture from previous cultures in East Texas becomes tedious when trying to fit the available archaeological record to existing models of Woodland cultures. Krieger stated (Suhm and Krieger 1954:158) that there was no evidence in East Texas of a Woodland (or Hopewellian) culture, with Mississippian culture beginning as early as 500 B.C. I mention this partly for the sake of argument, but also to point out that in this area there is not such a clearcut difference between the archaeology of Woodland and Early Caddo cultures. If Krieger is correct, it might make better sense to have a Formative phase of Caddo rather than trying to make a Woodland culture fit the transition from Archaic to Caddo.

Based on current thinking, Caddo culture developed around A.D. 800-900, based primarily on work conducted at the George C. Davis site. In Smith County there seem to be few sites that fit into what has been termed either the Formative and Early Caddo (A.D. 800-1200) periods or Alto phase sites as defined at the Davis site. Rather, in this area, Caddo culture reached a florescence during the following Middle Caddo (A.D. 1200-1400) time period, at least in the number and visibility of sites on the landscape. Then, for reasons that we do not fully understand, this area was apparently abandoned by prehistoric groups.

There is some question whether Caddo culture was introduced to the area either by the actual movement of peoples or an infusion of ideas, or rather developed out of the traditions of existing cultures; more likely, both processes took place. Assuming for the moment that the Caddo culture in this area evolved out of an existing culture (with an infusion of new ideas? - the glue that held it all together), what would that culture be? The
Woodland period (1000-500 B.C. to A.D. 800 ) is characterized by the introduction of several new technologies: introduction of the bow and arrow, more intensive agriculture in some areas, but there is little evidence to support this in East Texas, and the use of pottery. This is in conjunction with a more sedentary lifestyle. Sites of this time period have as diagnostic traits some combination of the following: small contracting stem Gary dart points, stemmed arrow points such as the Friley and Steiner types, and pottery, mostly plain, and never in great amounts. Supposedly the cultures associated with the Woodland period lead to the development of what we call Caddo culture.

One idea put forth by Schambach (1970) is that Caddo culture evolved out of the Fourche Maline culture with its particular traits. Another idea, put forth by Story (1990), is that Caddo culture evolved from not one predecessor group but rather from several different groups with distinct but relatively similar sub-traditions, these being the: (1) Arkansas River Valley; (2) Woodland edge; (3) Red River valley; and (4) Piney Woods. However, the Woodland culture in the Smith County area differs in some degree from the Fourche Maline culture on the Red River and the Mossy Grove/sandy paste culture in the southern part of the Piney Woods. On several grounds, Perttula defined this area between the two as being occupied during the Woodland period by the Mill Creek Culture (Perttula and Nelson 2004:155-170). In this part of East Texas, the Woodland sites differ from Fourche Maline in that they lack the intense middens and large amounts of pottery that otherwise characterize Fourche Maline sites; there are also no chipped hoes or Poole pipes. The sandy paste ceramic tradition of the Mossy Grove culture does not extend this far north into the northern part of Smith County. The Mill Creek sites appear to have been smaller and occupied for shorter time periods than is the case with Fourche Maline sites in the Red River valley, for instance, and are 
lacking the intense middens associated with the latter sites. There also seems to be very little pottery associated with these sites when compared to later Caddo sites.

Differences between Woodland and Caddo sites in this area include:

1. The sheer volume and stylistic diversity of pottery on Caddo sites. Vessel forms such as bottles are apparently absent on Woodland sites. Engraving scarce or absent on Woodland sites;

2. Lack of permanent structures and absence of burials on Woodland sites;

3. Evidence of domesticated plants, especially maize, lacking on Woodland sites;

4. Discrete middens only on Caddo sites;

5. Evidence of celts on Caddo sites, especially from southwestern Arkansas and southeastern Oklahoma source areas, but not on Woodland period sites;

6. Decreasing reliance on stone tools, especially the decreasing evidence of arrow points on Caddo sites;

7. More local materials employed in chipped stone tool manufacture on Woodland sites;

8. Evidence of differences in status between peoples living on Caddo sites;

9. Caddo sites appear on higher elevations on the landscape than do Woodland sites; and

10. The existence of a dual ceramic tradition on Caddo sites, with both fine and utility ware vessels with contrasting rim and body designs.

\section{EXAMPLES OF RELEVANT SITES IN SMITH COUNTY}

\section{Browning Site (41SM195A)}

The Browning Site is one example of the Mill Creek culture in this area of East Texas (Walters 2004). The main occupation is dated by radiocarbon and Oxidizable Carbon Ratio dating to between A.D. 600-800. This date and associated artifacts indicate it was occupied during the latter part of what has been termed the Woodland period in the region.

Friley and Steiner are the most commonly recognized types of arrow points collected at the Browning site. Other stone tools include flake tools, seven ferruginous sandstone ground stone tools, and 12 dart points (with small Gary points the most common type).

The 40 sherds from the Browning site are discussed in detail by Walters (2009). It is noteworthy that the ceramics at the Browning site closely resemble later Caddo ceramics in thickness, surface treatment, firing, and hardness, and to some extent with respect to vessel decoration, and they would be very hard to separate from the ceramic sherds on any nearby Caddo assemblage. Twenty-eight $(70 \%)$ of the sherds are grog-tempered. Another $15 \%$ have grog/hematite temper. Four (10\%) have a combination of grog and bone as tempering agents; none of these sherds have an abundance of bone. Two $(5 \%)$ sherds have no discernible temper. Twentysix $(65 \%)$ of the sherds have been fired and cooled in a reduced oxygen atmosphere. Thirteen $(32.5 \%)$ were fired in a reducing atmosphere, and then allowed to cool in the open air. One sherd $(2.5 \%)$ was completely oxidized during firing.

Six of the sherds at the Browning site are decorated. Three body sherds have single straight incised lines, while two sherds had two parallel straight incised lines; the distance between the incised lines ranges from 12.2-13.0 $\mathrm{mm}$. The one decorated rim has a single straight horizontal incised line on it. A second rim is from what appears to be a plain carinated bowl.

The amount of ceramics at the Browning site is meager when compared to later Caddo sites in the area that are distinguished by their sheer volume of sherds. At the Browning site, the sherd density is only 1.96 sherds per $\mathrm{m}^{3}$. By comparison, in excavations at the $14^{\text {th }}$ century A.D. Leaning Rock (41SM325) Caddo site, the sherd density is 280.4 sherds per $\mathrm{m}^{3}$ (Walters 2008). It is uncertain why there are so few sherds represented at Mill Creek culture sites compared to what is seen on Fourche Maline or Mossy Grove sites, but evidently ceramics played a minor role in the lives of the people that lived at the Browning and other Mill Creek sites.

\section{Boxed Springs Mound Site (41UR30)}

The Boxed Springs site is an Early Caddo (ca. A.D. 900-1200) multiple mound center in 
the middle reaches of the Sabine River (Perttula and Wilson 2000). The site consists of four mounds arranged around a plaza with borrow pits, midden areas, and at least one large Caddo cemetery where some 150 graves were looted. Sam Whiteside excavated Mound A, a circular burial mound, in the 1960s (Figure 1), uncovering a rectangular pit with evidence of at least three individuals. This burial is quite similar to several shaft burials at the Gahagan mound site on the Red River in northwestern Louisiana, in that the latter were large rectangular tombs with multiple interments with grave goods placed along the walls and in the

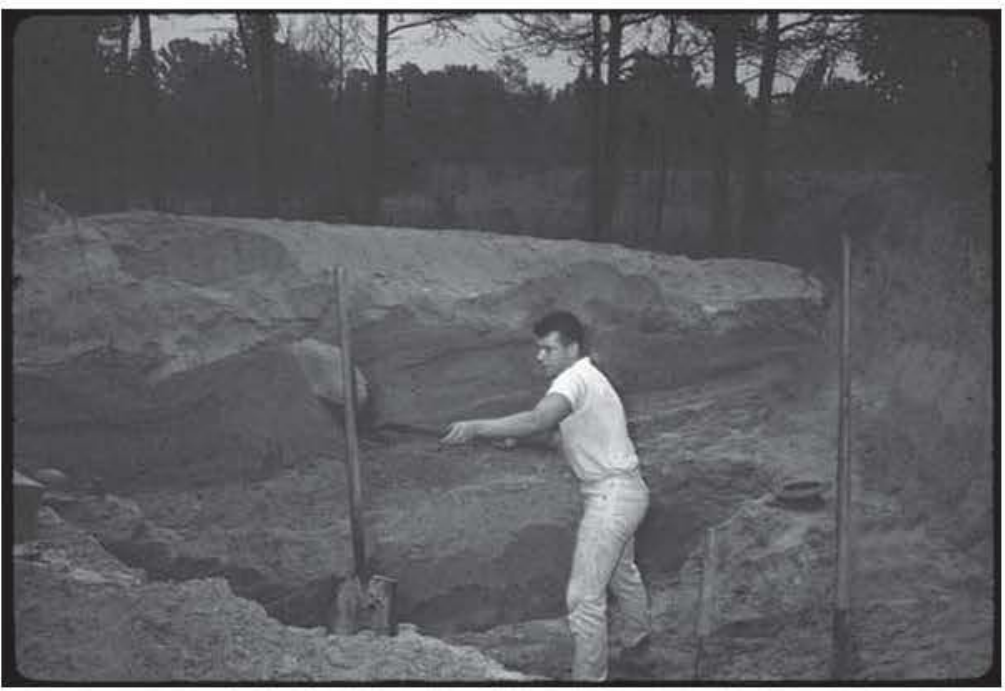

Figure 1. Mark Walters assisting in the ca. 1960 excavations in Mound A at the Boxed Springs site. corners of each tomb.

Offerings in the Boxed Springs burial tomb included 55 arrow points (Alba, Hayes, and Catahoula-like) in four clusters. There were also two large Gahagan bifaces, five celts, and polishing stones in the tomb. Additional grave goods included seven ceramic vessels: two plain bottles; a Spiro Engraved beaker; an everted rim jar with a pinched body decoration and zoned incised-cane punctates; a plain carinated bowl; and two plain jars. Ceramic vessels and sherds from other excavations and the looted cemetery include examples of Holly and Hickory Fine Engraved, Spiro Engraved, Coles Creek Incised, Weches Fingernail Impressed, Kiam Incised, East Incised, Crenshaw Fluted, and Crockett Curvilinear Incised.

\section{Holmes Site (41SM282)}

There is one known example in Smith County of a site with Lower Mississippi Valley ceramics such as Coles Creek Incised but with no Caddo ceramics. These sherds (from the J. A. Walters collection) are from the Holmes site on Simpson Creek in eastern Smith County. Simpson Creek drains to the north to the Sabine River, and the site is located near the headwaters of Simpson Creek in a wide valley where several small streams come together to form Simpson Creek. Dee Ann Story and Robert Mallouf recorded a possible mound (41SM62) in this vicinity in 1978.

The first sherd is a jar rim with a suspension hole (Figure 2a). The rim is direct and has a rounded lip; its orifice diameter is $20.0 \mathrm{~cm}$. The sherd is from a vessel that was fired in a reduced atmosphere and it had grog temper. It is classified as Coles Creek Incised, var. Coles Creek, with horizontal incised lines that are slightly overhanging and smoothed.A row of triangular punctates have been placed below the horizontal lines. The sherd was submitted a few years ago for instrumental neutron activation analysis and the results indicated the vessel was made from local clays. The next sherd (Figure $2 b$ ) is from the same vessel. There is another example of Coles Creek, var. Coles Creek from the site that is a body sherd (Figure 2d).

Two sherds are decorated with randomly or freely-placed v-shaped tool punctates. One sherd is a rim, slightly everted, with a rounded lip (see Figure 2e). It comes from a vessel fired in a reduced atmosphere; charred plant materials were the only temper. Decoration on the sherd consists of randomly or freely-placed $v$-shaped tool punctates. The other $\mathrm{V}$-shaped punctated sherd is a body sherd from a vessel fired in a reduced atmosphere. It has been tempered with grog and small, finely crushed bone; the sherd also has a sandy paste with visible quartz grains. The sherd is also decorated with v-shaped random tool punctates defined by a single straight incised line (see Figure 2f).

The last sherd is a body sherd with grog temper. The sherd came from a vessel that had been fired in a reduced atmosphere. The decoration on the sherd is similar to Marksville Stamped, var. Troyville with dentate rocker stamping (see Figure $2 \mathrm{c}$ ). 


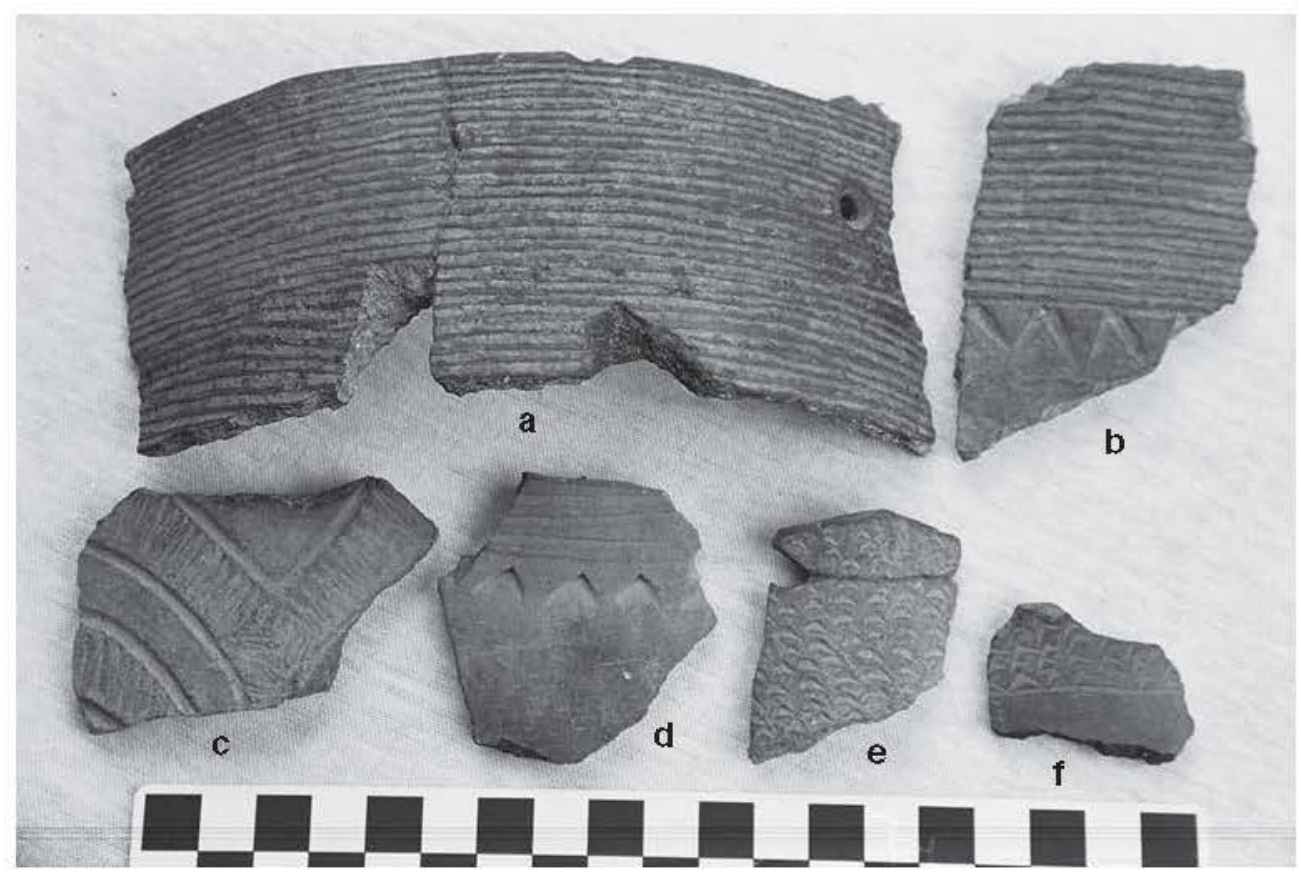

Figure 2. Lower Mississippi Valley sherds from the Holmes site (41SM282): a-b, d, Coles Creek Incised, var. Coles Creek; c, Marksville Stamped, var. Troyville; $\mathrm{e}-\mathrm{f}, \mathrm{v}$-shaped random tool punctated.

\section{Henry Chapman site (41SM56) on Prairie Creek}

The Henry Chapman site (41SM56) has examples of Early Caddo pottery (see Walters, this volume). Holly Fine Engraved and Hickory Fine Engraved wares are common in the ceramic assemblage, although few examples are as well executed as the examples from the George C. Davis site. Whether this means that the Smith County sites date later in time or were just poor copies of the vessels that were being produced at the Davis site is not known. Other examples of Early Caddo ceramic types present at the Henry Chapman site are Crockett Curvilinear Incised, Davis Incised, and Pennington PunctatedIncised; Weches Fingernail Impressed, found on many Early Caddo sites, is absent.

\section{REFERENCES CITED}

Perttula, Timothy K. and Bo Nelson

2004 Woodland and Caddo Archeology at the Broadway or Kanduts'ah Kuhnihdahahdisa' Site (41SM273) on the City of Tyler-Lake Palestine WTP Project, Smith County, Texas. Report of Investigations No. 50. Archeological \& Environmental Consultants, LLC, Austin.
Perttula, Timothy K. and Diane E. Wilson, with contributions by Mark Walters

2000 An Early Caddoan Period Cremation from the Boxed Springs Mound Site (41UR30) in Upshur County, Texas, and a Report on Previous Archaeological Investigations. Journal of Northeast Texas Archaeology 12:31-71

Schambach, Frank F.

1970 Pre-Caddoan Cultures in the Trans-Mississippi South: A Beginning Sequence. Ph.D. Dissertation, Department of Anthropology, Harvard University.

Story, Dee Ann

1990 Cultural History of the Native Americans. In The Archeology and Bioarcheology of the Gulf Coastal Plain, by Dee Ann Story, Janice A. Guy, Barbara A. Burnett, Martha D. Freeman, Jerome C. Rose, D. Gentry Steele, Ben W. Olive, and Karl J. Reinhard, pp. 163-366. 2 Vols. Research Series No. 38. Arkansas Archeological Survey, Fayetteville.

Suhm, Dee Ann and Alex D. Krieger

1954 An Introductory Handbook of Texas Archeology. Bulletin of the Texas Archeological Society 25:1-562.

Walters, Mark

2008 Life on Jackson Creek, Smith County, Texas: Archeological Investigations of a $14^{\text {th }}$ Century Caddo Domicile at the Leaning Rock Site (41SM325). Caddo Archeology Journal 17:1-114. 
2009 Prehistoric Ceramics from the Browning Site (41SM195A). Journal of Northeast Texas Archaeology 29:1-7.
Walters, Mark, with contributions by Phil Dering, Timothy K. Perttula, LeeAnna Schniebs, Marilyn B. Shoberg, and Betty Inman

2004 41SM195A, The Browning Site. Journal of Northeast Texas Archaeology 20:1-42. 